\title{
Faith-Based Peacebuilding Through Intercultural Dialogue
}

\section{Mohsen Ghanbari}

\author{
Al-Mustafa International University, Qom, I. R. Iran \\ Seyed Hidayat Ali Shah \\ Al-Mustafa International University, Qom, I. R. Iran
}

\begin{abstract}
Addressing the root causes of conflicts among people, peace practitioners attempted to present their peacebuilding models in order to build peace in a context of fighting individuals, groups, and societies. Islamic faith-based peacebuilding that is derived from the main sources of Islamic thought the Qur'an and the Sunna - is the model by which Muslim peacebuilders have tried to solve the problems of Muslim world.

The outstanding figure of Islamic peacebuilding is Prophet Muhammad, as he is introduced to be a perfect role model for all humanity in all times. Therefore, we have a glance at the Prophet's tradition in order to illuminate how he behaved in a multicultural and multireligious environment of $\mathrm{Me}$ dina while attempting to build an integrated community. Dialogue was a tactic that the Prophet used in dealing with people by reciting the glorious Qur'an and issuing the Charter of Medina to unify the diverse society of Medina under a new culture of Muslim brotherhood and Umma.
\end{abstract}

Keywords: Islam, the Qur'an, faith-based peacebuilding, culture, intercultural and interfaith dialogue, Prophet Muhammad, Medina Charter, Muslim brotherhood

Corresponding author: mghanbari@miu.ac.ir

Corresponding author: razavi786@gmail.com 


\section{Introduction}

Today we are witnessing different manifestations of mischief, oppression, tension, violence and enmity among people which are rooted in human ignorance and people's detachment from spirituality and divinity. Seeking an outlet, traumatized individuals and communities struggle to relieve their pain from which they are suffering, while striving for peace and tranquility. From among those peacebuilding models, faith-based peacebuilding that is derived from the main sources of Islam - the Qur'an and Sunna - focuses on an interreligious as well as intercultural dialogue to facilitate peace and justice, and to deescalate conflict and oppression.

The Prophet Muhammad, as he is introduced to be a perfect role model for all humanity, was taken as a model of Islamic faith-based peacebuilding in this paper for the purpose of illuminating the path toward sustainable peace and justice. Therefore, the Prophet's tradition in a multi-cultural society of Medina and his way of social unification under the shadow of Medina Charter created a new culture of Muslim Umma-building leading to social faith-based peace.

Illustrating the terms: peacebuilding, faith-based peacebuilding, culture and intercultural dialogue, Prophet Muhammad's peacebuilding model in Medina, Medina Charter, I will present faith-based peacebuilding as a model which helps us to reach peace through a dialogue with people from various religious and cultural backgrounds.

\section{Peacebuilding}

The first concept that should be unveiled here is the word peacebuilding, the meaning of which is to be discussed at length in this paper. While Johan Galtung defines peacebuilding as a reconciliation of past traumas, a resolution of conflict, and a construction of equity and harmony (Galtung, 2012), John Paul Lederach observes peacebuilding in terms of relationships. Lederach developed a peacebuilding pyramid, outlining that relationships are one key tool against violence. The pyramid consist of three levels in peacebuilding;

1) The grassroots level, as the bottom-up work for peace;

2) Leaders at the top of the pyramid, as the top-down work for peace;

3) In the middle Lederach placed people that work both with the grassroots and the leaders for peace. 
According to Lederach, this pyramid has been constructed by referring to the web peacebuilding theory and the way a spider weaves its web and hooks it up to a few strategic spots, with the threads extending from those spots intersecting at the center of the web. He stated that sustainable realtionship-based peacebuilding is to:

1) Understand the social context by building a network connected to strategic positions that carry the network, through developing relationships with people who are situated differently in the social context.

2) Construct the web where people are present, where people are situated as that is the core interconnecting the network.

3) Be flexible and smart, responsive and adaptive to the changing environment.

Lederach argued that a sustainable way to build peace is by creating a web of relationships, a network that includes our enemies. Lederach further emphazed that peacebuilding is adaptability, the capacity to respond and adapt in a dynamic environment (see: Lederach 2005), and what is called the Medina Charter of the Prophet Muhammed would be used as a model for network peacebuilding embraced by both Muslims and non-Muslims, as well as by the people of the Book.

On the other hand, Lisa Schirch argues that peacebuilding is most often used as an umbrella term to encompass other terms, such as conflict resolution, management, mitigation, prevention, or transformation. ${ }^{1}$ For Schirch, peacebuilding is preferred to focus on the larger goals of peace and security rather than on the problem of conflict. Conflict-related terms focus on the negative and embue whole regions with their experience of conflict rather than with their capacity for peace (see: Schirch 2008: 1-17).

1 Schirch illustrates those similar terms in this way: The term "conflict resolution" is useful when communicating to the general public and to the funders who generally understand this term. Yet there is a variety of problems with the term "conflict resolution". First, many believe it implies too much finality. Conflicts rarely end neatly. A second related concern is that the term de-legitimizes nonviolent forms of resistance and struggle, thus problematizing "conflict" and not violence, and by extension inherently supporting the status quo structures of power. The term "conflict transformation", on the other hand, communicates that conflict is indeed transformed rather than managed or resolved. However, which way the transformation is happening and what is being transformed remains unclear. The term "conflict prevention" refers to efforts to build peace proactively, to prevent violent conflicts. Since the field of peacebuilding teaches that conflict is normal and can be a positive opportunity for bringing about needed changes, if handled constructively, some note that it is violence, not conflict, that should be prevented. 
Therefore, peacebuilding is an umbrella-term including all attempts at building peace practiced by the pyramid of peace builders: leaders, middle class, and grassroots, in order to build relationships through web peacebuilding for peaceful coexistence. Web peacebuilding would help the peacebuilders to understand the social context, to construct a peace network through connecting people in peaceful coexistence, and finally to be responsive to encountering the changing and multi-cultural environments.

In this paper, we will be envisioning an Islamic peacebuilding model through the lens of network peacebuilding in Medina, as established by the Prophet Muhammad, the most perfect faith-based peacebuilding figure.

\section{Culture}

Without knowing culture and cultural diversities of a conflicting context, peace builders have no capability of confronting the problems and building peace. Therefore, the main culture under which a variety of people are interconnected and coexisted is the channel through which peace practitioners would set up their peacebuilding mission. Indeed, culture is the social behavior and norms found in human societies, and it is considered a central concept in anthropology, encompassing a range of phenomena that are transmitted through social learning in human societies. According to the Merriam Webster (Macionis \& Gerber 2011), culture would be defined as:

A: the integrated pattern of human knowledge, belief, and behavior that depends upon the capacity for learning and transmitting knowledge to succeeding generations;

B: the customary beliefs, social forms, and material traits of a racial, religious, or social group; also: the characteristic features of everyday existence (such as diversions or a way of life) shared by people in a place or time;

C: the set of shared attitudes, values, goals, and practices that characterizes an institution or organization.

Considering the definition of a human being as a civic being (Aristotle, book 1, chapter 7), different aspects of human social manifestation are generally called culture, which shows itself through relations within the network peacebuilding. 


\section{Dialogue}

Dialogue as a form of communication can build an intersubjective network to reach a physical net of peaceful coexistence in a diverse society. The etymology of the word 'dialogue' is from the Greek 'dialogos', with 'dia' meaning 'through' or 'across', and 'logos' meaning 'word,' 'meaning' or 'reason'. The Merriam-Webster dictionary presents a common definition of dialogue as "a conversation between two or more persons". In the Oxford Dictionaries, dialogue as a noun is defined as a discussion, specifically addressing a subject or for the purpose of resolving a problem.

The goal of a dialogue is to understand the other, which is not possible except by listening. The phase of listening before speaking helps one to understand the other better before speaking to them. After listening, the focus in a dialogue is on openly sharing one's own point of view. Since dialogue is a reflective form of communication, changing one's opinion through internalizing thoughts, considerations and impressions from communications is seen as a strength. Dialogue thus requires a degree of openness to others and to oneself. Openness includes allowing emotions, along with reflections, stories and faith, thus making space for the whole person.

\section{Intercultural dialogue}

By an intercultural or interfaith dialogue we mean a conversation between different individuals or groups, whose purpose is simply an honest engagement and increased mutual understanding with a respect for the cultural values, including the religious ones, of the counterparts. This kind of dialogue is very different from a debate, in which case we seek to win an argument, to persuade others of our point of view. It is also different from discussion, which aims to solve a problem, reach a consensus or decide on a course of action. In an intercultural dialogue, we engage with others for the sake of relationship; we are looking simply for a meaningful humanistic and cultural interaction through which we may grow in understanding of the other, of ourselves and of the linkage between us in order to make a strong network of peacebuilding.

We take benefit of Martin Buber's observation (Buber 1971) of a true dialogue here as a kind of interaction that provides understanding through direct experience of the other. He saw it as a genuine, transformative encounter between the participants seeing and responding to each other as persons, not as things that they might use as a means to an end. For Buber, a dialogue is a deeply meaningful interpersonal experience, which can change you, as it can help you see yourself from the perspective of the other. In 
accordance with David Bohm ${ }^{1}$, we can have a range of learning that can take place in a dialogue. A person who engages in an intercultural dialogue not only becomes aware of the realities of other cultures, but also aids himself in revising his own culture and deepening his own faith. This process, as explored by David Yankelovich (Yankelovich 1999), may potentially transform conflict into cooperation and peaceful coexistence in a multicultural context, if it occurs under three particular conditions:

- equality (or at least a suspension, as far as humanly possible, of inequality and coercive influences);

- listening with empathy in order to understand, and

- bringing assumptions out into the open.

These conditions are undoubtedly helpful in facilitating the sort of a genuine human encounter that Buber envisioned, in which we meet the other as a valued human person, setting aside power games and the impulse to control or use others for our ends. Through the effort to meet others as equals, to listen with empathy, and to be open about our preconceptions and prejudices, we may break down some of the barriers in the way of a meaningful cultural and religious interaction. For dialogue practitioners, the full achievement of all three conditions is perhaps something to aspire to: an ideal set of circumstances in which a really profound dialogue may take place.

Therefore, a dialogue is a verbal communication with other human beings who are interconnected to one another for mutual understanding and respect inside the web of cultural various demonstrations meant to implement peacebuilding.

\section{Faith-based peacebuilding}

The whole procedure of peacebuilding through an intercultural dialogue practiced by Muslim peacebuilders was taken as faith-based peacebuilding rooted in their strong commitment to the Islamic Sharia derived from the Qur'an and the tradition of the Prophet Muhammad. Many Muslim and non-Muslim scholars have identified values and principles in Islam, such as: monotheism and unity in following one God (Qur'an 21: 92), a merciful Prophet to the whole world (21:107) and taking him as a role model (33:21), being submissive to guardians, al-Awlia; God, the Prophet and Imams (3:32), accountability for all actions on the day of resurrection (37:24), Justice, Adl

1 One of the most interesting and influential contemporary theorists in the field of a dialogue. 
(5: $8 ; 57: 25 ; 16: 90 ; 4: 58 ; 42: 15)$ and peace $(2: 208)$ that are interconnected. The notion that peace cannot be achieved without justice is echoed by many peacebuilding researchers and activists (see: Lederach 1997). These values are supported by innumerable verses in the Qur'an, commanding believers to be righteous and levelheaded in their dealings with their fellow beings.

Considering the above mentioned principles, the Qur'anic verses can be applied as the indicators to faith-based peacebuilding as classified in the following manner:

\section{The reality of diversity}

The Qur'an explains that the free will of human beings caused a kind of diversity in religion and culture clarifying how to respond to it with righteousness and justice:

Say, Now the truth has come from your Lord: let those who wish to believe in it do so, and let those who wish to reject it do so (18:29).

There is no compulsion in religion (2:256).

Had your Lord willed, all the people on earth would have believed. So can you [O Prophet] compel people to believe (10: 99)?

If God so willed, He would have made you all one people (16: 93).

These verses indicate that the diversity out of human free will was intended by God. This requires us to learn how to live peacefully through an intercultural as well as an interfaith dialogue. Other verses from the Qur'an show us the divine wisdom in such diversity, encouraging us to engage:

We have assigned a law and a path to each of you. If God had so willed, He would have made you one community, but He wanted to test you through that which He has given you, so race to do good: you will all return to God and He will make clear to you the matters you differed about (5: 48).

If your Lord had pleased, He would have made all people a single community, but they continue to have their differences - except those on whom your Lord has mercy - for He created them to be this way (11:118-19). 


\section{Honoring human beings}

In his book-dialogue on Islam (Erol 2012), Erol observes Muslims' positive engagement with their fellow human beings from different cultural and religious backgrounds. A dialogue is a natural manifestation of our humanness, as both the Qur'an and the life of the Prophet make it clear. The Qur'an tells us that the fundamental oneness of all human beings and their ethnic and linguistic plurality together enable us to engage with and to understand one another:

And indeed We have honored the Children of Adam, and We have carried them on land and sea, and have provided them with al-Tayyibat (lawful good things), and have preferred them above many of those whom We created with a marked preference.

(Qur'an 17: 70)

Based on the divine will for honoring human beings, we have to share our humanity with all individuals and communicate with them in order to reach peaceful coexistence. This honored human being is created not only to connect to other people but to communicate with God, the creator, by worshiping Him.

I created jinn and mankind only to worship Me (51: 56).

Worship itself is a form of communication and a dialogue with God. According to some exegesis of the Quran (Tabatabaei 1995), worship in this verse is Knowing God. The process of Knowing God requires us to start our spiritual journey within ourselves in order to discover the inner world (which, for Imam Ali, is a large world) and the external world, the horizons. This long contemplation necessitates a human being to connect meaningfully with himself as an honored creature, with the universe as the divine communication, and to God as his Creator. A dialogue in this procedure has a great role in building communication with all the engaging parties.

\section{Mutual Understanding}

A dialogue of an honored human being with other people from different nations and ethnic groups leads us to our origin from a single man and a single woman, which is the departure point of a human being towards communication and being together. This special kind of engagement facilitates mutual understanding for all members of humanity. Thus, a dialogue can 
contribute to stable, peaceful relations between different groups to figure out which one is more connected to God and the most honored by Him.

O people, We created you all from a single man and a single woman, and made you into races and tribes so that you should get to know one another. In God's eyes, the most honored of you are the ones most mindful of Him: God is all knowing, all aware (49: 13).

\section{Problem solving}

According to Islamic faith-based peacebuilding, a peacebuilder should be starting with the external shared problems taking them to Islamic holy scriptures (Sadr 2007: 121). If a peacebuilder takes the global problems such as moral degeneration, environmental pollution, unfair distribution of economic gains, disease, poverty, collapse of family values, fanaticism in the name of race, religion and nationalism, and problems threatening the world peace such as terrorism, war and exploitation to the Qur'an asking for the solution, the Qur'anic answer for a problem solving dialogue is a consultation that is considered as a conducting method for the great affairs.

Consultation in the Qur'anic usage is the peacebuilder's asking for taking assistance from people around him by way of a dialogue and practicing finally on a decision made out of the process of a dialogue.

And those who answer the call of their Lord and perform the prayer and who (conduct) their affairs by mutual consultation, and who spend of what We have bestowed on them. (42:38)

And by the Mercy of Allah, you dealt with them gently. And had you been severe and harsh-hearted they would have broken away from about you; so pass over (their fault), and ask (Allah's) Forgiveness for them; and consult them in affairs. Then when you have taken a decision, put your trust in Allah, certainly, Allah loves those who put their trust (in Him). (3: 159)

\section{Qur'anic Classification of People}

As Erol observed, the Qur'anic text distinguishes three groups: (i) Believers, who believe in One God and the teachings of the Prophet $\mathrm{Mu}$ hammad. Hypocrites are included within the group of Muslims since they were outwardly pretending to be believers even as they were inwardly defecting from Islam and scheming against the Muslims. (ii) Unbelievers 
and polytheists, who are classed together as mushrikin, who deny God or associate a partner with God, and (iii) the People of the Book, referring to those who follow a divine book and a prophet sent by God, and these people include Jews, Christians, and Sabians.

The [Muslim] believers, the Jews, the Christians, and the Sabians those who believe in God and the Last Day and do good - will have their rewards with their Lord. No fear for them, nor will they grieve (2: 62).

For the [Muslim] believers, the Jews, the Sabians, and the Christians - those who believe in God and the Last Day and do good deeds there is no fear: they will not grieve (5: 69).

As for the believers, those who follow the Jewish faith, the Sabians, the Christians, the Magians, and the idolaters, God will judge between them on the Day of Resurrection; God witnesses all things

(22: 17).

\section{A dialogue with the People of the Book}

Becoming aware of the Qur'anic classification of people, we have to know whom the Qur'an encourages us to communicate and converse with. The People of the Book are a class on which Islam put a great emphasis and pushed Muslims forward to engage in a dialogue with upon the commonalities.

Say, People of the Book, let us arrive at a statement that is common to us all: we worship God alone, we ascribe no partner to Him, and none of us takes others beside God as lords. (3: 64)

[Believers], argue only in the best way with the People of the Book, except with those of them who act unjustly. Say, 'We believe in what was revealed to us and in what was revealed to you; our God and your God is one [and the same]; we are devoted to Him. (29: 46)

\section{A dialogue with common people}

Imam Ali classifies people in his letter to Malik Ashtar in two main groups: our brothers in faith or those similar to us in creation (Sharif Radiy 1992: 49). Accordingly, we must respect not only those who share our faith but also the group of people who share the nature of creation with us. So 
based on this doctrine, we communicate with them through a dialogue and mutual respect in order to build peaceful coexistence in a shared environment. The Qur'anic verse indicates:

And He does not forbid you to deal kindly and justly with anyone who has not fought you for your faith or driven you out of your homes: God loves the just (60: 8).

The non-Muslims mentioned in this verse clearly include any non-Muslims, not just the People of the Book.

\section{Islamic Peacebuilding Model Based on the Prophet Muhammad's Tradition}

Now to make this paper more practical and problem-based research, we firstly must start moving from the external problem of peacebuilding toward the Islamic Model of peace in Medina (the tradition of the Prophet Muhammad), and secondly we must move within the context of early Islam in Medina in order to discover the Islamic peacebuilding model for the Muslims' behavior in their everyday life. This way of referring to Islam is called "making the silent scripture to be talking" by the Martyr Sadr (Sadr 2007: 39). Considering this model, we organize this section of paper into three parts of early Islam in Medina:

\section{Islamic Peacebuilding:}

To begin with the Islamic peacebuilding practiced by the Prophet in Medina, we would clarify four elements of the Peace in Medina, Muhammad the Peacebuilder, Anthropology and the Environment of peace in Medina for deepening our understanding about early Islam and applying its teaching in daily life.

\section{A. Islam as the whole message of peace in Medina}

Islam as the perfect example of faith-based peacebuilding was being developed gradually during 23 years of the Prophet Muhammad's mission. Considering the cultural diversity of different contexts, Islam was founded in Mecca and persisted in Medina to be perfected in Sharia, a universal system for managing both individual and social human life.

The holy Qur'an addressed people of Mecca with "Ya Ayyuha al-Nas" ("Oh, People!"), to show its universal mission to the diverse society, and 
addressed people of Medina with "Ya Ayyuha Allazin Amanu" ("Oh, Faithful People!"), to build a faithful community of new believers based on peace and happiness. The given peace in Medina created a new cultural system in which religious rituals paved the way for social solidarity and integrity. The Qur'an in Medina attempts to generate a new culture of relationship among the Prophet Muhammad and his followers, and the other inhabitants of the city such as Munafiqin, the hypocrites and the People of the Book (Khorramshahi 1998: 154).

\section{B. Peacebuilder of Medina}

Accounts of the Prophet Muhammad's life show that he had been a model of positive engagement with those around him before he was called to be a prophet, since before that time he had been known as al-Sadiq al-Amin, the truthful and the trustworthy. Thus, at that time, he positively engaged with others not in obedience to the revealed word of God, the Qur'an, but in obedience to the norms of God's creation - the innate disposition, fitra, with which God endowed all human beings.

The Prophet Muhammad, the perfect Islamic role model, the faith-based peacebuilder, started his mission from Mecca by internalizing the inner peace through piety, Taqwa, within the soul of the faithful individuals and continued his peacebuilding in Medina in order to build a faithful community by implementing the Islamic Sharia system.

Peacebuilding traits of Muhammad, the faithful peacebuilder, in Medina are the following:

1. Emphasizing training and educating people by reciting the verses of the Qur'an, building mosques, instilling Muslim brotherhood into the Immigrants, Muhajirin, and the Helpers, Ansar for creating new relationship.

2. Trying to establish an Islamic political system on three pillars: a) the believers as the peaceful members of the new community; b) Sharia as an authentic system of Law which guarantees peace and its implementation; and c) paving the way to the faithful community building that is the embodiment of peace.

3. Making peace with the neighbors of Islamic community and the People of the Book in order to spread the peace originated from the Muslim community to the region.

4. Globalizing the mission of faith-based peacebuilding by sending invitation letters and messengers to the empires of that time.

5. Redefining the values and shifting them from wealth and genealogy 
of the ignorance to human faith-based dignity. The verse "verily the most honored of you in sight of God is the most righteous of you" (Qur'an 49: 13) creates a new system of judging the values and human dignity. Based on this measure, Bilal, a former slave, became a Muazzin, caller for prayer (Waqidi 1989: 203).

Zaynab bint Jahsh, of a noble family, married Zeyd bin Harehha, the slave of Kadija (Tabari 1996: 302), a faithful person among other believers who was considered to be a part of a single body provided that if he were in pain, others would be in pain as well (Ibn Sa'd 1985: 33).

\section{Anthropology of Medina}

Knowing people of Medina helps us to customize what the Prophet did for them in terms of peace and reconciliation, as well as for the contemporary peace practitioners of the world.

1. Contrary to the people of Mecca, who were mostly ignorant and pagans, the people in Medina had lived in peaceful coexistence with the People of the Book for a long time (Shirazi 1990: 203). The People of the Book were monotheists and the people of Medina became introduced to this transcendent doctrine of monotheism.

2. The People of the Book used to have the culture of waiting for the last Prophet of God in Medina (Qur'an 2: 89) Despite the Jewish rejection of the new Prophet, the divine doctrines of the Holy Scripture affected the population in the region and paved the way for welcoming the Prophet who emigrated from Mecca to Medina.

3. The long conflict between two great tribes in Medina, Aws and Khaz$r a j$, and their exhausting situation before Hijra led them to seek a peacebuilder to resolve their lasting conflict. Therefore, they found the Prophet Muhammad to be the savior as well as a peacebuilder.

4. The tribal culture and a warm welcome with which the heads of the tribes greeted the Prophet, caused the people of Medina to accept the Prophet Muhammad.

In such a community, the Prophet took the opportunity of his addresses in different culture, and used his noble background to be the promised one for the People of the Book, a peacebuilder for the warring tribes, and finally a merciful leader for the community. This teaches us how a peacebuilder can transform a conflict presented in a society to build peace and integrity. 


\section{Environment of Medina}

Before knowing the environment of Medina, it is important to have a glance at the background of the environmental shift from Mecca to Medina in order to understand the Hijra strategy as an element of faith-based peacebuilding. During a 13-year prophecy, the Prophet Muhammad took the opportunity of tribal relationships and invited people to the new religion. $\mathrm{He}$ knew well that the Quraysh cannot assassinate him because they were afraid of confronting Bani Hashim and butting themselves in the situation of war in Mecca. Therefore, the trouble they caused to the Prophet was a kind of defamation, accusation, and less a physical type of damage (Shahidi 2011: 204).

Although a tribal society had some benefits, it was not a proper ground to establish one faith-based Umma. So the Prophet decided to turn the limited environment into the ideal one in which the integrated structure of Umma settled (Ibn Kathir 1991: 303). To get more knowledge about the environment, two critical concepts in pre-Islam-Medina should be taken into consideration, Autom, the castle, and Rab'a, tribal independent culture.

Autom as a symbol of territorial independence was a building with a tall watchtower for defending a particular tribe against the enemy. Because of possessing a vast land, Medina had many Automs used as shelter for the inhabitants in a state of threat. Indeed, the peaceful spirit of the people in Medina, because of which on the one hand they did not need any political or military agreements, and on the other they lacked central power, caused the tribes in Medina to feel constant insecurity and lasting conflict between two or more tribes (Ali 2012: 183). Rab'a was the cultural independence of a tribe enabling it to organize its social relations, customs and traditions, which helped distinguishing one tribe from the others.

The two former concepts help us to deepen our perception of the people of Medina as living in a state of fear because of the absence of a centralized political system to unify the scattered tribes. This culture helped the Prophet to play the role of a great leader who governed the society, and of a peacebuilder who replaced the state of fear with peace, stability, and integrity.

\section{Peacebuilding phases:}

Prophet Muhammad used proper means for his faith-based peacebuilding in Medina, such as: 1) the glorious Quran as the main source of peacebuilding, that is a divine dialogue with the Prophet and which repeated the word Qul, say, three hundred and thirty-three times (Abdulbaqi 1945: 348) to show God's emphasis on a dialogue in which the message is conveyed by the Messenger to the audience (Qaramaleki 2014: 18); 2) innovating some reli- 
gious institutions: the Mosque, as the first cultural center established by the Prophet after Hijra to be the place of dialogue with God through worship and of people through sermons of the Prophet; 3 ) resisting psychological warfare launched by the enemies (Nasr 2001: 189); 4) good interaction with the People of the Book and convincing them that all the previous prophets had been sent by God and that they were all part of a single stream and the common religion of peace and submission to God, and that there was no difference in prophecy (Qur'an 3: 83, 84). Therefore, a differentiation between true and false Christians and Jews, and justice in judgment between them were some of the ways through which the noble Prophet communicated with the People of the Book. (Zargarinejad 2005: 13); 5) Sending out messengers to different corners of the region to recite the Quran and teach the new religion, Islam, and to give charity (Alviri 2004: 21). 6) Appointing 12 middle-class peacebuilders calling them Naqeeb for taking assistance from them in the process of peacebuilding in the context of tribal conflict. The Prophet addressed 12 Naqeeb saying "you as the Apostles of Jesus Christ are the chiefs of your tribes, and I am the chief of my own people" (Tabari 1996: 935).

\section{The Medina Charter}

The Charter of Medina is a document drafted by the Prophet Muhammad shortly after his arrival at Medina (see: Watt 1961) for the purpose of building faith-based peace and granteeing sustainable peace in the Muslim community. The document is a book of the Prophet Muhammad which instructs one how to act between the believers and Muslims from the Quraysh tribe and from Yathrib, and those who may be under them and wage war in their company, declaring them to constitute one nation Umma including all individuals of a diverse society. It established the collective responsibility of nine constituent tribes for their members' actions, specifically emphasizing blood money and ransom payment. The first constituent group mentioned are the migrants from Quraysh, followed by eight other tribes. Eight Jewish groups are recognized as part of the Yathrib community, and their religious separation from Muslims is established. The Jewish Banu Al Shutbah tribe is inserted as one of the Jewish groups, rather than with the nine tribes mentioned earlier in the document. The constitution also established the Prophet Muhammad as the mediating authority and peacebuilder among those groups and forbids waging war without his authorization. The constitution formed the basis of a multi-religious Islamic community in Medina (see: Firestone 1999).

The constitution was created to end the bitter intertribal conflict between the rival clans of Aws and Khazraj in Medina (Serjeant 1978: 33) and 
to maintain peace and cooperation among all groups in Medina. Establishing the role of the Prophet Muhammad as the peacebuilder between the two groups and the others in Medina was central to the ending of internal violence in Medina and was an essential feature of the constitution. The document ensured freedom of religious beliefs and practices for all members who follow the believers. It imposed a tax system for supporting the community in times of conflict. It declared the role of Medina as a Haram, (Hamidullah 1998: 134), or a sacred place, where no blood of the peoples included in the pact can be spilled. Haram indeed is a place of peace with God and God's creation, indicating that Islam is a religion of peace and that a community embraces Islam is a peaceful community.

One of the most important feature of the Constitution of Medina is the redefinition of the ties among the Muslims. It sets faith-based relationships above blood-ties and emphasizes individual responsibility. Tribal identities are still important when referring to different groups, but the main binding tie for the newly-created Umma is religion. That contrasts with the norms of pre-Islamic Arabia (Serjeant 1978: 34).

The non-Muslims had the following rights, on the condition they followed the Muslims:

1. The security of God is equal for all groups,

2. The non-Muslim members have the same political and cultural rights as the Muslims. They have autonomy and freedom of religion.

3. The non-Muslims take up arms against the enemy of the nation and share the cost of war. There is to be no treachery between the two.

4. The non-Muslims are not obliged to take part in the the Muslims' religious wars (see: Ahmad 1979: 239).

By the Medina Charter, the Prophet renewed the social relations of the community and founded a network of peacebuilding based on faith. This intercultural and interfaith charter teaches the Muslim peacebuilders today to have an Umma-building perspective by recognizing the cultural and religious diversity within a vast framework of being together based on commonalities.

\section{Peacebuilding strategy:}

The main strategy of the Prophet Muhammad in Medina pertains to innovating the social ties among individuals of that environment, which are called a religious brotherhood. Contemplating on that notion would help religious communities to switch from conflict to peace and solidarity. 


\section{A. Muslim brotherhood and faith-based unity}

The historical background of the concept of religious brotherhood in the culture of the early Islam is older than the Prophet making pacts of brotherhood between the Muhajirin and the Ansar after his migration from Mecca to Medina. One of the oldest usage of the notion of brotherhood among Muslims is the one made by the Muslims in Mecca about their fellow Muslims in Yathrib (or Medina) before they migrated there (Ibn Kathir 1991: 169).

Five or eight months after the migration of Muslims to Medina, the Prophet told his Sahaba: "Every pair of you be brothers in the way of God". There is a disagreement among historians with respect to the number of the Muslims. According to many sources, there were 90 people: 45 from the $\mathrm{Mu}$ hajirin (those who had migrated from Mecca to Medina) and 45 from the Ansar (residents of Medina who helped the migrants) (Ibn Husham 1976: 327).

One of the main concerns of the Prophet was to establish social justice among all people (Qur'an 57:25), and this required, on the one hand, a collapse of social classes, and, on the other, an establishment of close relations and affinities among individual peoples. Thus, the Prophet established the relation of religious brotherhood as a practical strategy to form brotherhood and equality among all people.

Before the brotherhood verse (49: 10) was revealed, it would have been thought that the establishment of religious brotherhood was merely a wise and intelligent strategy by the Prophet as a religious and political leader in order to solidify the foundations of the newly emergent Islamic community and provide a spiritual support for it. However, the revelation of the brotherhood verse showed that such a relation was, in addition to being a political strategy to unify the Islamic nation, a part of the Islamic doctrines legislated by God.

\section{B. Procedures of Making a Pact of Brotherhood}

Making this notion more applicable for the peacebuilding process by Muslim peacebuilders, we bring here the procedure through which Islamic brotherhood may take place. To begin with the pact, two men or two women shake each other's right hands, with one of them reciting the verbal vow of brotherhood and the other accepting it.

Here is the verbal vow (see: Nuri 1988): "For the sake of God, I will be your brother and I will be honest with you, and for the sake of God, I will put my hand in your hand, and before God, His angels, his holy scriptures, and his prophets, I promise that if I deserve to go to the heaven and I am allowed to intercede for you, then I will not enter the heaven without you". 
And then the other party responds: "I accept".

Then the first speaker says: "I do not give you any rights of brotherhood except those of intercession, praying, and visits".

And again the other party responds: "I accept".

The verbal vow does not need to be recited in Arabic; it can be recited in any language, but the words should convey the meanings of this vow.

Received: November 23 ${ }^{\text {rd }}, 2018$.

Accepted: December 27 ${ }^{\text {th }}, 2018$.

\section{References}

The Holy Qur'an.

Abdulbaqi, Muhammad Fuad (1945), Al Mu'jam al Fihris li Alfaz al Qur'an, Cairo, Dar al Kutub al Misriyya.

Ahmad, Barakat (1979), Muhammad and the Jews, Noida, Vikas Publishing House.

Ali, Salih Ahmad (2012), The State of Allah's Apostle (Dulate Rasule Khoda), Qom, Pajuheshgahe Hawza va Daneshgah.

Alviri, Mohsen (2004), The Prophet's Cultural and Communicational Practices (Shivehaye Farhangi va Ertebatiye Payambar), Tehran, Imam Sadiq University.

Buber, Martin (1971), I and Tho, New York, Simon and Schuster.

Erol, Mustafa Kasim (2012), Dialogue in Islam; Qur'an, Sunnah, History, London, Dialogue Society.

Firestone, Reuven (1999), Jihad: The Origin of Holy War in Islam, Oxford, University Press.

Galtung, Johan (2012), A Mini Theory of Peace; Building Direct Structural Cultural Peace, Grenzach-Whylen, Transcend University Press.

Hamidullah, Muhammad (1998), The Letters and Treaties of Prophet Muhammad (Nameha va Peymanhaye Hazrate Muhammad), Tehran, Surush.

Ibn-Husham, Abd al Malik (1976), The Prophet's Tradition (al Sira al Nabawiyya), Cairo, Dar al Mảrifa.

Ibn Kathir, Abul Fida Ismail (1991), Al Bidaya wa al Nihaya, Beirut, Dar al Ma'rifa.

Ibn Sa’d, Abu Abdullah Muhammad (1985), Al Tabaqat al Kubra, Beirut, Dar Beirut Press.

Khorramshahi, Bahaodin (1998), The Encyclopedia of the Qur'an and Qur'anic Studies, daneshnemeye Qur'an wa Qur'anpajuhi, Tehran, Dustan-Nahid.

Lederach, John Paul (1997). Building Peace: Sustainable Reconciliation in Divided Societies, New York, Syracuse U. Press.

Lederach, John Paul (2005), The Art and Soul of Building Peace, New York, Oxford University Press. 
Macionis, John J. \& Gerber, Linda Marie (2011), Sociology, Toronto, Pearson Prentice Hall.

Nasr, Seyyed Hossein (2001), Psychological War (Jange Ravani), Tehran, Sorush Press.

Nuri, Mirza Husain (1988), Mustadrak al Wasail, Beirut, Alul Bayt Institute.

Qaramaleki, Abol Fazl (2014), "The Manifestation of Divine Dialogue in the Qur'anic Usage of the Term Qul (Tajalliye Khodaye Goftegu dar Karborde Qur'aniye Qul)", Pajuheshnameye Tafsir va Zabane Qur'an 2 (2): 7-21.

Sadr, Muhammad Baqir (2007), Al Madrasa al Qur'aniyya, Qom, Research Center for the Matyr Sadr.

Schirch, Lisa (2008), "Strategic Peacebuilding; State of the Field Peace Prints", South Asian Journal of Peacebuilding 1 (1): 1-17.

Serjeant, Robert Bertram (1978), "Sunnah Jāmi'ah, Pacts with the Yathrib Jews, and the Tahrim of Yathrib: Analysis and Translation of the Documents Comprised in the So-Called 'Constitution of Medina'”, Bulletin of the School of Oriental and African Studies 41 (1): 1-42.

Shahidi, Seyyed Jafar (2011), Analytical History of Islam (Tarikhe Tahliliye Eslam), Tehran, Daneshgahi Press Institute.

Sharif Radiy, Abul Hasan (1992), Nahj al Balaghah, Letter 53. Tehran, Bonjade Nahj al Balaghah.

Shirazi, Makarem (1990), Tafsire Nemune, Tehran, Dar al Kutub al Islamiyya.

Tabari, Muhammad Baqir (1996), The History (Tarikh), Tehran, Asatir.

Tabatabaei, Muhammad Husain (1995), Al Mizan fi Tafsir al Qur'an, Qom, Jami’a Mudarrisin Hawza ilmiyya Qom.

Waqidi, Muhammad ibn Omar (1989), Al Maghazi, Beirut, al A'lami Press Institute.

Watt, William Montgomery (1961), Muhammad: Prophet and Statesman, Oxford University Press.

Yankelovich, Daniel (1999), The Magic of Dialogue, New York, Simon and Schuster.

Zargarinejad, Gholam Hosein (2005), The History of Early Islam (Tarikhe Sadre Islam). Tehran: Samt. 